\title{
Optimasi Pemilihan Supplier dan Alokasi Supply Batubara Pada PLTU Kapasitas 615MW dengan Menggunakan Metode Analytical Hierarchy Proces dan Goal Programming (Studi Kasus PT.XYZ)
}

\author{
Muhammad Asvin Imaduddin, dan Edwin Riksakomara \\ Departemen Sistem Informasi, Fakultas Teknologi Informasi,Institut Teknologi Sepuluh Nopember \\ (ITS) \\ e-mail: asvin.imaduddin@gmail.com,erk@is.its.ac.id
}

\begin{abstract}
Abstrak-Supplier merupakan salah satu mitra bisnis yang memegang peranan dalam menjamin ketersediaan barang pasokan yang dibutuhkan oleh perusahaan. Pada perusahaan yang baik dan sehat ketika kondisi supplier tidak sedang baik maka perusahaan tidak terlalu mendapatkan kerugian. Pemilihan supplier sendiri merupakan salah satu kegiatan strategis bagi perusahaan dalam proses bisnisnya apabila supplier memasok barang barang yang kritis dan dalam jangka waktu yang panjang bagi perusahaan sehingga perusahaan harus dapat mempertimbangkan dengan baik pemilihan supplier tersebut. Dalam mengatasi masalah tersebut, penulis mencoba mengimplementasikan pendekatan analytical hierarchy process dengan goal programming dengan terintegrasi, sehingga dapat menghasilkan hasil yang baik dalam pemilihan supplier dengan kriteria lebih dari satu, sesuai dengan kriteria yang telah ditentukan oleh perusahaan. Pada hasil penelitian didapatkan bukti bahwa metode AHP dapat digunakan dengan baik untuk membantu proses pemilihan supplier dengan 3 kriteria dan 7 subkriteria. Luaran selanjutnya dari penelitian ini ialah alokasi supply batubara yang dipasok supplier pada perusahaan dan sesuai dengan target biaya minimum, waktu pengiriman minimum, dan kualitas batubara yang optimal. Hasil proses pemilihan supplier dengan menggunakan metode AHP didapatkan hasil 3 terbaik dari 12 supplier dengan nilai pada PT. H sebesar 81.6, PT F sebesar 80.2, dan PT. I sebesar 79.6. Dalam jangka waktu satu tahun PT. H mendapatkan alokasi supply sebesar 3000000 ton, PT. F sebesar 500000 ton, dan PT. I sebesar 500000 ton.
\end{abstract}

Kata Kunci-Pemilihan supplier, supplier batubara, alokasi supply, analytical hierarchy process (AHP), Goal Programming.

\section{PENDAHULUAN}

$\mathrm{E}$ nergi merupakan aspek penting bagi kehidupan manusia dan berpengaruh besar bagi perkembangan suatu negara dalam bidang sosial maupun ekonomi. Pertumbuhan dari kebutuhan suatu energi juga tidak bisa dipisahkan dengan ekonomi. Hal ini dikarenakan kebutuhan energy yang terus menerus meningkat namun sumber daya energi yang ada terbatas. Sehingga dibutuhkannnya perencanaan dan pengolahan energi yang tepat guna dan tepat sasaran.

Dalam perencanaan \& pengelolaan energy listrik, pengadaan bahan bakar untuk pengelolaan energi merupakan hal yang vital. Dimana bahan bakar Pembangkit Listrik Tenaga
Uap berupa batu bara merupakan salah satu sumber daya alam yang tidak dapat diperbaharui. Batu bara sendiri bukan merupakan sumber daya alam yang tidak terbatas. Bahkan Indonesia diperkirakan terancam krisis batubara pada tahun 2035 [1]. Hal ini dikarenakan cadangan batu bara yang dimiliki oleh Indonesia hanya sebanyak 8 miliar ton saja, sedangkan konsumsi domestik yang dibutuhkan negara sebesar 170 ton batubara pertahun. Selain itu juga memungkinkan adanya percepatan krisis tersebut dikarenakannya harga batu bara yang tidak sebanding dengan harga operasional penambangan batubara [2].

Sejak diberlakukannya UU Nomor 15 Tahun 1985, Peraturan Pemerintah Republik Indonesia Nomor 10 Tahun 1989 dan Keputusan Presiden Nomor 37 Tahun 1992, Pemerintah Republik Indonesia memberikan ijin perusahaan swasta untuk berbisnis di bidang pembangkit listrik dan menjual hasil listrik pada Perusahaan Listrik Negara (PLN) [3]. Maka dari hal tersebut dari beberapa perusahaan asing penanam modal membutuhkan perencanaan pengoptimalan untuk mengelola bahan bakar dari pembangkit tersebut, yaitu salah satunya ialah dengan mengoptimalkan pemilihan supplier batubara serta megalokasikan supply batubara pada proses produksi.

Supplier merupakan salah satu mitra bisnis yang memegang peranan dalam menjamin ketersediaan barang pasokan yang dibutuhkan oleh perusahaan. Sebuah perusahaan yang sehat ialah perusahaan yang tidak terlalu berpengaruh apabila supplier yang dimiliki oleh perusahaan tersebut sedang mengalami masalah berupa kualitas yang kurang maksimal maupun pengiriman yang terlambat. Maka dari itu perusahan harus dengan cermat dalam memilih supplier-nya [4].

Pemilihan supplier sendiri merupakan salah satu kegiatan strategis bagi perusahaan dalam proses bisnisnya. Hal ini juga menjadi suatu hal yang sangat penting bagi perusahaan apabila supplier tersebut memasok barang yang penting bagi perusahaan dan dengan jangka waktu yang panjang. Dalam pemilihan supplier, dibutuhkan berbagai kriteria guna menggambarkan performa dari supplier sehingga dapat membantu pembuat keputusan dalam menentukan keputusannya.

Keputusan untuk memilih supplier pada bahan non kritis pada perusahaan sangat mudah, namun untuk memilih 
beberapa supplier pada bahan kritis bagi perusahaan dibutuhkan beberapa kriteria yang mampu memastikan secara tepat pilihan supplier tersebut.Wisner et al (2009) memberikan pendapat tentang beberapa kriteria antara lain, teknologi yang digunakan dalam proses produksi, kemauan untuk membagi dan informasi, kualitas, harga, kehandalan, sistim dan waktu pemesanan, kapasitas, kemampuan untuk berkomunikasi, lokasi, dan pelayanan [5].

Kesalahan dalam melakukan pemilihan supplier dapat meningkatkan biaya produksi yang lebih besar. Hal tersbut dapat dibuktikan pada penelitian sebelumnya bahwa pada dasarnya pengeluaran terbanyak, sekitar 70\%, Merupakan biaya yang digunakan untuk pembelian material dan komponen produksi [6]. Maka dari itu peranan supplier sangat penting bagi pasokan material yang dibutuhkan perusahaan.

Pada studi kasus mengenai pemilihan supplier serta pengalokasian supply, sebelumnya pernah dilakukan oleh Chin-Nung Liao [7] dengan menggunakan 3 metode yang diintegrasikan antara Taguchi Loss Function, Analytical Hierarchy Process, dan Multi-Choice Goal Programming dengan kasus calon supplier lebih dari satu dan memiliki 7 kriteria. Pada penelitian ke-2 yang dilakukan oleh O. Jadidi [8] membuktikan bahwa pada studi kasus pemilihan supplier dapat diselesaikan dengan metode Goal Programming beserta pengembangan dari Goal Programming. Selanjutnya pada penilitian ke-3 yang dilakukan oleh A. Amid [9] membuktikan bahwa fuzzy multiobjective dapat digunakan untuk menyelesaikan permasalahan pemilihan supplier dengan tujuan biaya, kualitas, dan lama pengiriman barang.

Studi kasus dalam penelitian ini ialah pada PT. XYZ, yaitu merupakan perusahaan pengelola pembangkit tenaga listrik uap dengan kapasitas 615MW. Dimana pada perusahaan ini kebutuhan batubara dipasok oleh beberapa supplier dengan berbagai macam kualitas, spesifikasi , harga, serta kapasitas pasokan. Maka dari itu karena pelanggan (PLN) telah meminta dengan batasan spesifikasi tertentu sehingga perusahaan memilih supplier yang tepat serta menentukan jumlah alokasi pesanan yang optimal. Dimana pada kenyataannya saat ini pemilihan supplier hanya berdasarkan harga dan intuisi dari pembuat keputusan.

Pada proses pengambilan keputusan dalam menentukan supplier penulis menggunakan metode Analytical Hierarchy Process untuk menilai supplier berdasarkan kriteria kriteria yang dimiliki perusahaan. Dan selanjutnya hasil penilaian tersebut digunakan sebagai koefisien fungsi tujuan pada model Goal Programming untuk menetukan kuantitas order. Metode AHP dipilih dikarenakan melibatkan beberapa kriteria yang memiliki struktur hubungan kompleks serta metode yang mudah dipahami [10].

Batasan pada penilitian ini antara lain untuk kriteria kualitas hanya meliputi nilai kalor, moisture, ash, sulfur, dan HGI. Selanjutnya Waktu pengiriman dan ketersediaan untuk kriteria kapabilitas, dan kriteria biaya

\section{METODOLOGI}

\section{A. Identifikasi Permasalahan}

Pada tahap ini akan dilakukan penggalian data dan analisis permasalahan yang berkaitan dengan topik studiberupa pemilihan supplier serta alokasi pemesanan batubara pada PT. XYZ. Proses penggalian data \& analisa permasalahan tersebut dilakukan dengan metode wawancara dengan pihak PT.XYZ selaku perusahaan pengoperasi PLTU. Dikarenakan dalam menentukan supplier perusahaan hanya membandingkan harga dan pemilihannya terbatas dengan menggunakan intuisi dari bagian middle \& top management.

\section{B. Studi Literatur}

Pada tahapan studi literatur ini dilakukan pengumpulan referensi, yang berasal dari narasumber dari perusahaan, buku, penelitian sebelumnya, serta dokumen dokumen yang terkait. Dari beberapa referensi yang dikumpulkan dilakukan pengkajian mengenai konsep maupun metode yang akan digunakan untuk menyelesaikan permasalahan pada studiini.

\section{Pengumpulan Data}

Pada tahapan ini dilakukan pengumpulan data data dan wawancara yang berhubungan dengan penyelesaian tugas akhir. Data data tersebut didapatkan dari PT. XYZ selaku salah satu perusahaan pengelola PLTU. Data yang dikumpulkan antara lain:

- Kriteria kebutuhan batubara

- Data karakteristik supplier (harga,kualitas,dll)

- Data spesifikasi boiler

- Data kapasitas coal pile

- Data kebutuhan batubara

- Data pendukung lainnya

\section{Pembuatan Model dan Solusi}

Pada tahap ini akan dilakukan formulasi pada semua batasan dan parameter yang dibutuhkan menjadi model matematis. Untuk model yang akan dibuat ialah model Analytical Hierarchy Process (AHP) dan juga model Goal Programming (GP). Output dari model AHP ini ialah supplier dengan jumlah 3 supplier, dikarenakan aturan yang telah ditentukan oleh perusahan ialah sebanyak 3 supplier. Sedangkan penggunaan dari model GP digunakan untuk menentukan alokasi supply batubara pada perusahaan, dimana penggunaan GP ini dilakukan dikarenakan dalam kasus ini memiliki fungsi tujuan yang lebih dari satu dan tidak terpaut pada fungsi tujuan dengan tujuan meminimumkan biaya namun juga memaksimalkan kapasitas pembelian dan memaksimalkan kualitas batubara (Calorivic Value, Ash, Moisture, Sulfur, HGI)

\section{1) Pembuatan Model AHP}

Model AHP digunakan untuk memilih 3 supplier, dengan responden 4 orang, dari Departemen Engineering, Departemen Fuel \& Ash, dan Departemen Purchasing. Berikut ini tahapan tahapan pegerjaan AHP

- Dekomposisi Permasalahan

Penguraian permasalahan untuk menentukan tujuan. 
- Penentuan Kriteria

Penentuan Kriteria apa saja yang memungkinkan

- Pembuatan Hierarki

Pembuatan Hierarki untuk memetakan struktur kriteria, subkriteria, dan alternatif.

- Perbandingan Berpasangan

Guna menentukan prioritas dari kriteria maupun subkriteria

- Perhitungan Bobot Kriteria

Guna menghasilkan hasil yang mampu menjadi rujukan / referensi keputusan.

- Perankingan Supplier

Perankingan dengan memanfaatkan bobot dan scoring alternatif untuk mengambil keputusan.

\section{2) Pembuatan Model GP}

- Variabel Keputusan

Variabel Keputusannnya ialah alokasi pembelian batubara dari tiap supplier, total 3 supplier.

- Fungsi Tujuan

Meminimalkan biaya pengadaan batubara, Meminimalkan waktu pengiriman, Meminimalkan nilai kalor (CV), Meminimalkan kandungan ash, Meminimalkan kandungan moisture, Meminimalkan kandungan sulfur, Meminimalkan kandungan HGI

- Batasan

Batasan pada metode ini meliputi Budget Perusahaan, Kapasitas Coal Pile, Kuantitas yang dibutuhkan dalam 1 tahun

\section{E. Validasi Model}

Uji validasi dilakukan untuk membandingkan hasil alokasi order supplier batubara yang dihasilkan melalui bantuan tools Lingo dan QM. Apabila hasil yang dikeluarkan berada pada tingkat kesalahan (error) yang diperbolehkan maka model tersebut sudah dapat dikatakan valid.

\section{F. Uji Coba Skenario Alternatif}

Tahap ini dilakukan untuk menentukan alternatif dari solusi yang telah dibuat berdasarkan permasalahan yang ada pada penelitian.

\section{G. Analisa Hasil dan Penarikan Kesimpulan}

Dari tahap ini akan dilakukan analisa hasil optimasi yang telah dikerjakan. Setelah itu dilakukan penarikan kesimpulan dari pengerjaan penilitian ini. Sehingga dari dapat dimanfaatkan sebagai saran untuk mengembangkan perusahaan dalam menentukan serta mengalokasikan pemesanan batubara agar lebih baik lagi.

\section{H. Pembuatan Laporan Penelitian}

Pembuatan laporan ini dimaksudkan sebagai bentuk dokumentasi atas penelitian ini.

\section{PENGOLAHAN DATA DAN IMPELEMNTASI}

\section{A. Pengumpulan dan Pra-Processing Data}

Pengumpulan data dilakukan dengan cara pengajuan kuesioner dan wawancara mengenai data kebutuhan batubara, Data kemampuan boiler, dan data alternatif supplier. Untuk tahapp praproses data ialah pengumpulan hasil kuesioner penilaian kriteria dari 4 departemen.

\section{B. Skema $A H P$ \& Kriteria}

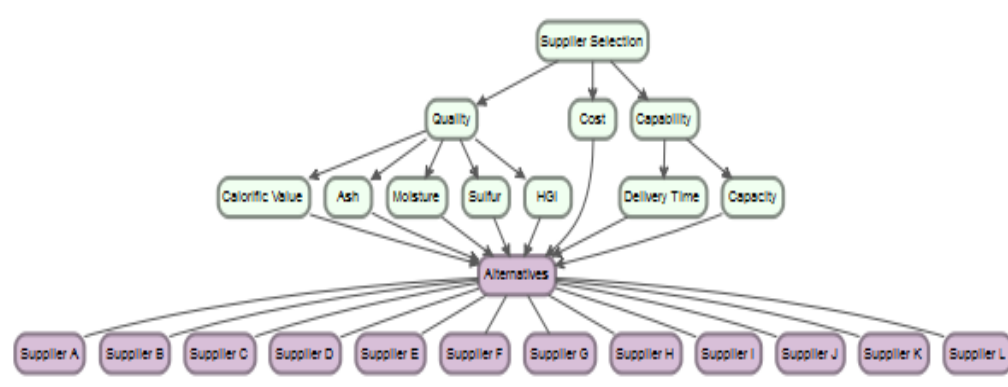

Gambar 1. Skema AHP

Dari skema tersebut dapat diketahui bahwa pada penelitian ini terdapat 3 kriteria yaitu Quality (dengan subkriteria CV, Ash, Moisture, Sulfur, dan HGI), Cost, Capability (dengan subkriteria Delivery Time dan Capacity). Sedangkan untuk alternatif supplier terdapat 12 supplier.

\section{Perbandingan Berpasangan}

Pada kriteria dilakukan perbandingan berpasangan dengan hasil scoring dibawah ini. Data tersebut berasal dari hasil kuesioner yang telah disebar.

Tabel 1. Perbandingan bobot kriteria

\begin{tabular}{llll}
\hline \hline Criteria & Quality & Cost & Capability \\
\hline Quality & 1 & 8.33 & 6.66 \\
Cost & 0.12 & 1 & 2,16 \\
Capability & 0.14 & 0.5 & 1 \\
\hline \hline
\end{tabular}

Selanjutnya pada subkriteria Quality dan Capability didapatkan hasil perbandingan berpasangan antara lain.

Tabel 2.

Perbandingan bobot subkriteria Quality

\begin{tabular}{|c|c|c|c|c|c|}
\hline \multirow{2}{*}{$\begin{array}{c}\text { Sub } \\
\text { Criteria }\end{array}$} & \multicolumn{5}{|c|}{ Quality } \\
\hline & $\mathrm{CV}$ & Moist & Ash & Sulfur & HGI \\
\hline $\mathrm{CV}$ & 1 & 8 & 7.67 & 4 & 5 \\
\hline Moist & 0.12 & 1 & 1.22 & 0.25 & 0.25 \\
\hline Ash & 0.12 & 0.8 & 1 & 0.28 & 0.25 \\
\hline Sulfur & 0.20 & 4 & 3.50 & 1 & 1.67 \\
\hline HGI & 0.20 & 4 & 4 & 0.6 & 1 \\
\hline $\begin{array}{l}\text { Column } \\
\text { Sum }\end{array}$ & 1.64 & 17.8 & 17.39 & 6.13 & 8.17 \\
\hline
\end{tabular}


Tabel 3.

Perbandingan bobot subkriteria Capability

\begin{tabular}{lrr}
\hline \multirow{2}{*}{ Sub Criteria } & \multicolumn{2}{c}{ Capability } \\
& Deliv Time & \multicolumn{2}{c}{ Capacity } \\
\hline Deliv Time & 1 & 3 \\
Capacity & 0.33 & 1 \\
Column Sum & 1.33 & 4 \\
\hline \hline
\end{tabular}

\section{Perbandingan Bobot}

Pada kriteria dan subkriteria dilakukan perhitungan bobot matriks dengan normalisasi dari hasil kuesioner .

Tabel 4.

Hasil penentuan bobot kriteria

\begin{tabular}{lrrrr}
\hline \hline Criteria & \multicolumn{1}{c}{ Quality } & \multicolumn{1}{c}{ Cost } & \multicolumn{1}{c}{ y } & \multicolumn{1}{l}{ Bobot } \\
\hline Quality & 0.78740 & 0.85098 & 0.67720 & $\mathbf{0 . 7 7 1 8 6 4 1 3 5}$ \\
Cost & 0.09448 & 0.10211 & 0.22121 & $\mathbf{0 . 1 3 9 2 7 5 3 1 4}$ \\
Capability & 0.11811 & 0.04689 & 0.10158 & $\mathbf{0 . 0 8 8 8 6 0 5 5 1}$ \\
\hline \hline
\end{tabular}

Tabel 5.

Hasil pnentuan bobot subkriteria quality

\begin{tabular}{lcccccc}
\hline \hline $\begin{array}{c}\text { Sub } \\
\begin{array}{c}\text { Criteri } \\
\mathbf{a}\end{array}\end{array}$ & CV & Moist & Ash & Sulfur & HGI & Bobot \\
\hline CV & 0.586 & 0.445 & 0.439 & 0.651 & 0.613 & $\mathbf{0 . 5 4 7 3 1 8}$ \\
Moist & 0.073 & 0.055 & 0.070 & 0.040 & 0.029 & $\mathbf{0 . 0 5 3 8 8 3}$ \\
Ash & 0.076 & 0.045 & 0.057 & 0.047 & 0.029 & $\mathbf{0 . 0 5 1 2 9 1}$ \\
Sulfur & 0.146 & 0.225 & 0.198 & 0.163 & 0.204 & $\mathbf{0 . 1 8 7 4 7 8}$ \\
HGI & 0.117 & 0.227 & 0.234 & 0.097 & 0.122 & $\mathbf{0 . 1 6 0 0 3 1}$ \\
\hline \hline
\end{tabular}

Tabel 6.

Hasil penentuan bobot subkriteria capability

\begin{tabular}{lrrr}
\hline \hline $\begin{array}{c}\text { Sub } \\
\text { Criteria }\end{array}$ & \multicolumn{2}{c}{ Capability } & \multicolumn{1}{c}{ Bobo } \\
Deliv Time & Capacity & \multicolumn{1}{c}{} \\
\hline Deliv & & & \\
Time & 0.75 & 0.75 & $\mathbf{0 . 7 5}$ \\
Capacity & 0.25 & 0.25 & $\mathbf{0 . 2 5}$ \\
\hline \hline
\end{tabular}

\section{E. Uji Konsistensi}

Pengujian CI (Consistency Index) dapat dilakukan dengan formula

$$
\mathrm{CI}=\frac{\left(\frac{\text { INîlai kommistansi kritaria }}{\text { jumlah kritaria }}\right)-\text { jumiah kriteria }}{\text { jumiah kriteria }-1}
$$

Apabila CI tidak sama dengan 0, maka dilakukan penilaian terhadap CR (Consistency Ratio) dengan formula

$$
\mathrm{CR}=\frac{G I}{R I}
$$

Dari perhitungan tersebut pada penelitian ini didaptkan nilai CI untuk kriteria 0.058 dengan $\mathrm{CR}=0.03$. Sedangkan CI subkriteria Quality 0.038 dengan $\mathrm{CR}=0.1$. Dan CI subkriteria Capability 0.

\section{F. Hasil Scoring}

Perhitungan indeks prefernsi dilakukan antara bobot kriteria dan subkriteria, dengan formula

Indeks Preferensi Kriteria_Subkriteria =

\section{Bobot Kriteria X Bobot Subkriteria}

Dan selanjutnya hasil tersebut dikalikan dengan hasil penilaian alternatif.
Maka didapatkan dengan 3 skor tertinggi Supplier tersebut antara lain PT. H ( dengan nilai 81.66256), PT. F (80.22636), PT. I (79.67521).

\section{G. Formulasi Data Goal Programming}

Tahap ini merupakan tahap pembentukan model Goal Programming. Variabel keputusan terdiri atas 3 variabel keputusan yaitu X1 (alokasi supplier peringkat pertama), X2 (alokasi supplier peringkat kedua), X3 (alokasi supplier peringkat ketiga) dan memiliki fungsi tujuan linear programming pada tiap sesinya (sesi 1 hingga sesi 6) antara lain

-Minimasi Biaya Pembelian Batubara

$\operatorname{Min} Z_{1}=\sum_{i=1}^{3} M_{i} X_{i}$

$Z_{1}=$ Total biaya pembelian batubara

$M_{\mathrm{i}}=$ Harga tiap ton batubara (USD)

$X_{i}=$ Alokasi supply supplier batubara .

-Minimasi Waktu Pengiriman

$\operatorname{Min} Z_{2}=\sum_{i=1}^{3} T_{i} X_{i}$

$Z_{2}=$ Total kebutuhan batubara terhadap waktu pengiriman selama satu sesi bulan

$T_{\mathrm{i}}=$ waktu pengiriman batubara supplier

-Maksimasi Nilai Kalor

$\operatorname{Max} Z_{\mathrm{a}}=\sum_{\mathrm{i}=1}^{\mathrm{a}} C_{\mathrm{i}} X_{\mathrm{i}}$

$Z_{\text {a }}=$ Total kebutuhan batubara terhadap persentase kecacatan selama satu sesi bulan

$C_{i}=$ Nilai kalor batubara tiap supplier

-Minimasi Kandungan Abu

$\operatorname{Min} Z_{4}=\sum_{\mathrm{i}=1}^{\mathrm{a}} A_{\mathrm{i}} X_{\mathrm{i}}$

$Z_{4}=$ Total kebutuhan batubara terhadap persentase kandungan abu pada batubara selama satu sesi bulan

$A_{\mathrm{i}}=$ Nilai kandungan abu batubara tiap supplier

-Minimasi Kandungan Sulfur

$\operatorname{Min} Z_{5}=\sum_{\mathrm{i}=1}^{\mathrm{a}} S_{\mathrm{i}} X_{\mathrm{i}}$

$Z_{5}=$ Total kebutuhan batubara terhadap persentase kandungan sulfur pada batubara selama satu sesi bulan

$S_{i}=$ Persentase kandungan sulfur pada batubara tiap supplier 
-Minimasi HGI

$\operatorname{Min} Z_{6}=\sum_{i=1}^{a} H_{i} X_{i}$

$Z_{6}=$ Total kebutuhan batubara terhadap nilai HGI

pada batubara selama satu sesi bulan

$H_{\hat{I}}=$ Nilai HGI pada batubara tiap supplier

Selanjutnya ialah fungsi batasan, pada penilitian ini untuk tiap sesinya, terdiri atas:

- Kebutuhan Batubara

-Sesi 1 (Januari - Februari)

$$
\sum_{i=1}^{3} X_{i} \geq 660000
$$

-Sesi 2 (Maret - April)

$$
\sum_{i=1}^{3} X_{i} \geq 668000
$$

-Sesi 3 (Mei - Juni)

$$
\sum_{i=1}^{3} X_{i} \geq 668000
$$

-Sesi 4 (Juli - Agustus)

$$
\sum_{i=1}^{3} X_{i} \geq 668000
$$

- Sesi 5 (September - Oktober)

$$
\sum_{i=1}^{3} X_{i} \geq 668000
$$

-Sesi 6 (Nopember - Desember)

$$
\sum_{i=1}^{3} X_{i} \geq 668000
$$

- Kapasitas stockpile

$$
\sum_{i=1}^{3} X_{i} \leq 670000
$$

- Alokasi order tiap supplier

$$
\begin{aligned}
& X_{(1)} \geq 83333.33 \\
& X_{(2)} \geq 83333.33 \\
& X_{(3)} \geq 83333.33
\end{aligned}
$$

\section{H. Implementasi Goal Programming}

Dari model Linear Programming yang dibuat sebelumnya diubah ke model Goal Programming. Fungsi tujuan pada Linear Programming berubah menjadi batasan dengan adanya target.
1. Memasukkan Fungsi Tujuan

Pada penelitiasn ini untuk mengimplementasi model goal programming digunakan aplikasi Lingo. Fungsi tujuan dari metode GP penelitian ini berubah menjadi meminimasi total deviasi.

2. Memasukkan Batasan

Batasan yang dimasukkan pada aplikasi Lingo sesuai dengan fungsi tujuan pada Linear Programming dan 3 batasan sesungguhnya

3. Menjalankan Fungsi Otomasi

Untuk mecari solusi optimal dari model,ialah dengan melalui tombol solver.

\section{HASIL DAN ANALISIS}

\section{A. Hasil Perhitungan AHP}

Dariperhitungan AHP didapatkan hasil ranking score keseluruhan supplier dengan hasil 3 skor tertinggi Supplier tersebut antara lain PT. H ( dengan nilai 81.66256), PT. F (80.22636), PT. I (79.67521)

\section{B. Validasi Model}

Validasi model merupakan suatu proses yang bertujuan untuk memastikan bahwa sebuah model yang telah dibuat sudah sesuai dengan tujuan yang diharapkan. Hasil Lingo dibandingkan dengan hasil aplikasi QM. Untuk menemukan persentase kesalahan digunakan perhitungan MAPE antara hasil Lingo dan QM. Didapatkan tingkat error untuk sesi 1 $9.04 \times 10^{-5} \%$ dan untuk sesi 2 hingga 6 bernilai $0.000121 \%$.

\section{Analisa Hasil}

Hasil optimasi menunjukkan alokasi supply batubara secara optimal pada tiap sesinya antara lain. Untuk tiap ton setiap supplier mempunyai harga yang berbeda beda PT. H seharga 59.7 USD, PT. F seharga 64.26 USD, dan PT. I seharga 62 USD. Dalam model GP diberikan pembobotan dari masing masing batasan baru, dimana bobot tersebut merupakan hasil pemodelan AHP dengan kriteria 6 kriteria yang memiliki hubungan dengan batasan baru, antara lain CV sebesar 0.467, Sulfur sebesar 0.145, Cost sebesar 0.139, HGI sebesar 0.117, Delivery Time sebesar 0.089, Ash sebesar 0.043.

Tabel 6.

Hasil penentuan bobot subkriteria capability

\begin{tabular}{lrrrr}
\hline \hline Sesi & PT. H & \multicolumn{1}{l}{ PT. F } & PT. 1 & \multicolumn{1}{l}{ Total Cost (USD) } \\
\hline 1 & 493333.3 & 83333.3 & 83333.3 & $\mathbf{3 9 9 7 3 6 6 4 . 2 6}$ \\
2 & 501333.3 & 83333.3 & 83333.3 & $\mathbf{4 0 4 5 1 2 6 4 . 2 6}$ \\
3 & 501333.3 & 83333.3 & 83333.3 & $\mathbf{4 0 4 5 1 2 6 4 . 2 6}$ \\
4 & 501333.3 & 83333.3 & 83333.3 & $\mathbf{4 0 4 5 1 2 6 4 . 2 6}$ \\
5 & 501333.3 & 83333.3 & 83333.3 & $\mathbf{4 0 4 5 1 2 6 4 . 2 6}$ \\
6 & 501333.3 & 83333.3 & 83333.3 & $\mathbf{4 0 4 5 1 2 6 4 . 2 6}$ \\
Total & 3000000.0 & 500000.0 & 500000.0 & $\mathbf{2 4 2 2 2 9 9 8 5 . 6 0}$ \\
\hline \hline
\end{tabular}

Total biaya dari keenam sesi tersebut didapatkan biaya sebesar 242229985.60 USD untuk memenuhi kebutuhan batubara selama satu tahun. Apabila dibandingkan dengan budget perusahaan selama setahun yang mana sebesar 
250000000 USD. Maka perusahaan menghemat anggaran sebesar 7770014.40 USD

\section{Uji Coba Skenario}

Uji coba skenario ini merupakan uji coba dengan menambahkan skenario tambahan. Skenario tambahan ini berupa penyetaraan bobot bagi tiap tiap batasan baru. Sehingga dari penyetaraan bobot tersebut akan menampilkan hasil pengalokasian yang optimal juga.

Hasil optimasi menunjukkan alokasi supplier batubara secara optimal. Untuk tiap ton setiap supplier mempunyai harga yang berbeda beda PT. H seharga 59.7 USD, PT. F seharga 64.26 USD, dan PT. I seharga 62 USD. Dari penggunaan bobot yang setara ini, didapatkan hasil yang sama. Dimana tidak ada perbedaan pada hasil alokasi dan deviasi.

\section{KESIMPULAN \& SARAN}

Metode Analytical Hierarchy Process dan Goal Programming dapat digunakan menyelesaikan permasalahan pemilihan supplier dan alokasi supply dengan melibatkan banyak tujuan,sehingga untuk melakukan proses optimasi alokasi supply dapat lebih mudah dan tepat sasaran.Proses validasi model dilakukan dengan mencoba membandingkan antara target dengan inputan hasil alokasi pada tiap variabel keputusan. Dari hasil tersebut dapat dinyatakan tiap fungsi tujuan linier programming yang menjadi patokan terpenuhi. Fungsi tujuan meminimalkan biaya pembelian batubara, meminimalkan waktu pengiriman batubara, memaksimalkan nilai kalor batubara, meminimalkan kandungan abu pada batubara, meminimalkan kandungan sulfur pada batubara, dan meminimalkan nilai HGI agar perusahaan dapat meminimumkan biaya dan dilain sisi tetap mendapatkan kualitas batubara yang optimal untuk bahan baku produksi listrik. Dari proses pemilihan supplier dengan menggunakan metode AHP dipilih 3 supplier dengan nilai masing masing tiap supplier antara lain PT. H sebesar 81.66256, PT. F sebesar 80.22636, dan PT. I sebesar 79.67521. Dan Dari Proses alokasi supply didapatkan hasil untuk sesi 1 PT. H mendapatkan alokasi sebesar 493333.3 ton batubara, PT. F sebanyak 83333.33 ton batubara, PT. I sebanyak 83333.33 ton batubara. Sesi 2 hingga 5, dikarenakan memiliki kebutuhan batubara yang sama, maka alokasi supply untuk PT. H sebanyak 501333.3 ton batubara, PT. F sebanyak 83333.33 ton batubara, PT. I sebanyak 83333.33 ton batubara

Saran kedepannya yang dapat dijadikan petimbangan apabila dilakukan penelitian lebih lanjut, pemilihan supplier dapat menggunakan kriteria tambahan, seperti data nilai volatile matter dari tiap batubara, data tingkat kecacatan batubara tiap supplier, kapasitas tongkang, data produksi batubara perbulan pada tiap tiap supplier, dan data data yang berkenaan dengan batubara yang notabene merupakan objek utama penentu supplier diterima ataupun tidak.Dan Data yang digunakan adalah data kebutuhan batubara dalam rentang lebih dari 1 tahun.

\section{DAFTAR PUSTAKA}

F. Ariyanti, "Indonesia Terancam Krisis Batubara di 2035," $\begin{array}{lll}\text { liputan6, } 2016 . & \text { [Online]. Available: }\end{array}$ http://bisnis.liputan6.com/read/2595197/indonesia-terancam-krisisbatu-bara-di-2035. [Accessed 10 December 2016.

[2] D. Divianta, "Produksi Batu Bara RI Turun 20 Persen," liputan6, 2016. [Online]. Available: http://bisnis.liputan6.com/read/2520316/produksi-batu-bara-riturun-20-persen?siteName=liputan6.

[3] A. A. S. Chamid, "Pemilihan Supplier Batubara dan Optimasi Alokasi Supply di PLTU Paiton Unit 7 dan 8.," Institut Teknologi Sepuluh Nopember, 2007.

[4] E. W. and E. Unbersa, "APLIKASI METODE ANALYTICAL HIERARCHY PROCESS DALAM MENENTUKAN KRITERIA PENILAIAN SUPPLIER," vol. 2, pp. 6-13, 2008.

[5] K.-C. T. and G. K. L. J. D. Wisner, Principles of Supply Chain Management: A Balanced Approach Third Edition. Nelson Education, Ltd, 2009.

[6] M. Gursoy, "A decision supportive method for multimodal freight transport mode choice: An example from Turkey," Iran. J. Sci. Technol., vol. 34, no. B4, pp. 461-470, 2010.

[7] C.-N. L. and H.-P. Kao, "Supplier selection model using Taguchi loss function, analytical hierarchy process, and multi-choice goal programming," Comput. Ind. Eng., vol. 58, pp. 571-577, 2010.

[8] S. Z. and S. C. O. Jadidi, "A new normalized goal programming model for multi-objective," Int. J. Prod. Econ., pp. 158-165, 2014.

[9] S. H. G. and C. O. A. Amid, "A weighted max-min model for fuzzy multi-objective supplier selection in a supply chain," Int. J. Prod. Econ., vol. 131, pp. 139-145, 2011.

[10] A. K. G. and M. J. Kristiandy, "INTEGRASI ANALYTIC HIERARCHY PROCESS DAN GOAL PROGRAMMING DALAM PEMILIHAN PEMASOK," J. Tek. Ind., vol. 14, no. 2, pp. 190199, 2013. 